УДК 628.1.032:543.32(477.81) https://doi.org/10.31713/vt2201915

Лапінський А. В., к.т.н., Кузьмінчук А. В., аспірант, Астрелін І. М., д.т.н., професор, Кримець Г. В., к.т.н. (Національний технічний університет України «Київський політехнічний інститут імені Ігоря Сікорського, м. Київ), Гаращенко О. В., к.т.н., доцент (Національний університет водного господарства та природокористування, м. Рівне)

\title{
ЗРАЗКОВА ПРИРОДНА ВОДА І ПРОБЛЕМИ ІЇ ЗБЕРЕЖЕННЯ У ВОДОЙМАХ РІВНЕНЩИНИ
}

Води поверхневих водойм Рівненського природного заповідника, зокрема, озера Біле, мають аномально низький солевміст та твердість. Цей факт підтверджують результати проведених нами багаторічних і системних досліджень проб води. В статті приведено аналіз відповідних систематизованих даних. Це дозволило зробити висновки про можливість застосування вод озера Біле як еталонних для випробування обладнання та комп'ютерного моделювання водоочисних процесів. Розглянуто чинники, що можуть мати негативний вплив на сольовий стан вод (зокрема наслідки видобутку бурштину).

Ключові слова: поверхневі води, низька твердість вод, біогенні елементи, фізико-хімічні дослідження складу води, бурштин.

Сучасні системи підготовки питної та технічної води повинні максимально відповідати потребам споживачів. Такі системи можуть бути як стаціонарними, так і мобільними, в тому числі, компактними, розрахованими на індивідуальне тимчасове застосування. До останніх можна віднести спеціальні трубки, в які вода всмоктується за допомогою м'язової сили людини. Тривалість їхнього надійного використання залежить, по-перше, від складу вихідної води, по-друге від набору фільтрувальних або інших матеріалів, з яких набирається комбінована насадка у трубках для водоочищення.

\section{Задача створення бази еталонних вод}

При первинному проведенні науково-прикладних досліджень фільтраційних матеріалів, сорбентів або інших реагентів та матеріалів використовуються, як правило, штучні модельні розчини, які містять ті чи інші забрудники, притаманні природним або забрудненим водам. Проте повномасштабне випробування засобів, реагентів та 
матеріалів щодо технічних характеристик можна провести лише за умови випробування їх для очищення реальних природних вод. Таким чином, виникає завдання, хоча б в межах України, мати набір зразків природних вод, які б мали статус еталонних за своїм складом. Такі води мають містити різноманітні домішки, мати стабільний склад протягом щонайменше кількох останніх десятирічь. Незмінність складу має також прогнозуватися і на приблизно таку ж перспективу. Фактично мова йде про «лінійки» зразків природних вод, які мають, наприклад, твердість від 0,1 до 12 ммоль-екв/дм³, загальний солевміст від 0,01 до 3000 мг/дм³

Створити базу даних таких зразків технічно можливо, проте, основна проблема полягає в тому, щоб знайти в природі, бажано на території заповідників, джерела природної води з низьким солевмістом та жорсткістю. Такі водойми є, певним чином, унікальними. Тому, з точки зору можливого залучення зразків таких вод як еталонних для проведення випробувань водоочисного обладнання треба водночас вирішувати два головних завдання:

- виявити і ретельно обстежити такі джерела природних вод;

- розробити надійну систему моніторингу і захисту цих природних джерел від техногенного та антропогенного впливу з метою підтримання їх складу у стабільному стані в середньо- і довготривалій перспективі, себто від 10 і більше років.

\section{Використання вод озера Біле, як еталонних}

Найтриваліші і регулярні моніторингові дослідження нами проводилися щодо сольового складу води озера Біле Володимирецького району Рівненської області.

Воно відноситься до території Рівненського природного заповідника. Його поверхневі водні об'єкти представлені системою річок, великими суміжними болотяними угіддями оліготрофного типу, озерами та системою старовинних меліоративних каналів XIX ст. Наші тривалі дослідження хімічного складу цих вод дають підставу вважати, що для всіх поверхневих водойм, які розташовані на території Рівненського природного заповідника, характерний низький солевміст, в тому числі, низька загальна твердість води. Фактично має місце брак основних біогенних макро- і напівмакроелементів: азоту, фосфору, калію, кальцію, магнію. Це непрямо підтверджується тим фактом, що, наприклад, в межах масиву Сира Погоня (відноситься до Рівненського природного заповідника) можна водночас зустріти дві хижих комахоїдних рослини, росичку круглолисту (D. rotundifollia L.) 
та товстянку звичайну (Pinguicula vulgaris).

В таблиці 1 наведено отримані нами в польових умовах методом крапельних експрес-тестів і уточнені в лабораторних аналізах дані щодо сольового складу вод озера Біле [1].

Твердість води визначалася трилонометричним методом. Загальний солевміст - за допомогою портативного солеміра «НІ 98302»

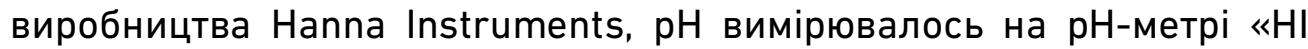
98129 Combo» виробництва Hanna instruments - в польових умовах і pH-метра «MW100» виробництва Milwaukee Instruments - в стаціонарних умовах. Загальний вміст азоту та загальний вміст фосфору визначався колориметрично в стаціонарних умовах.

Таблиця 1

Загальний солевміст і твердість води в озері Біле

Володимирецького району Рівненської області

(місце відбору - напроти рятувальної станції)

\begin{tabular}{|c|c|c|c|}
\hline Дата відбору & $\begin{array}{c}\text { Загальний солев- } \\
\text { міст, мг/дм }\end{array}$ & $\begin{array}{c}\text { Твердість зага- } \\
\text { льна, } \\
\text { ммольекв/дм }\end{array}$ & $\mathrm{pH}$ \\
\hline $\begin{array}{c}\text { Червень } \\
2011\end{array}$ & 47 & 0,86 & 8,0 \\
\hline $\begin{array}{c}\text { Червень } \\
2012\end{array}$ & 52 & 0,85 & 8,1 \\
\hline $\begin{array}{c}\text { Червень } \\
2013\end{array}$ & 49 & 0,85 & 8,1 \\
\hline $\begin{array}{c}\text { Червень } \\
2014\end{array}$ & 51 & 0,86 & 8,1 \\
\hline $\begin{array}{c}\text { Жовтень } \\
2014\end{array}$ & 50 & 085 & 8,1 \\
\hline $\begin{array}{c}\text { Червень } \\
2015\end{array}$ & 52 & 0,85 & 8,1 \\
\hline $\begin{array}{c}\text { Червень } \\
2016\end{array}$ & 49 & 0,87 & 8,0 \\
\hline $\begin{array}{c}\text { Червень } \\
2017\end{array}$ & 48 & 0,86 & 8,1 \\
\hline $\begin{array}{c}\text { Червень } \\
2018\end{array}$ & 53 & 0,88 & 8,0 \\
\hline
\end{tabular}

Тривалі дослідження вод озера Біле свідчать про високий рівень сталості їх сольового складу. Води можна віднести до низькомінералізованих, слаболужних та м'яких.

Сталість складу дає підстави для використання цих вод як од- 
ного з еталонів (нижняя межа) для випробування індивідуальних та інших водоочисних систем. Такий підхід повинен передбачати низку обов'язкових заходів природоохоронного характеру з метою збереження стабільності складу в довготривалій перспективі.

\section{Фактори впливу на склад низькозасолених вод озера Біле}

Чинником техногенного характеру, здатним несприятливо впливати на сольовий склад вод озера Біле в прогнозованій перспективі, $€$ наслідки легального та нелегального видобування бурштину в північно-західній частині України. Дослідженим і описаним вектором даної проблеми є масштабне знищення лісових масивів та родючих земель, але детальний міжгалузевий науковий аналіз відкриває нові напрямки. Фактори, що обумовлюють дані проблеми, є хімічними. Вони були виявлені під час хімічного моніторингу поверхневих вод на території Рівненського природного заповідника і прилеглих до неї місць «дикого» видобутку бурштину. Варто зауважити, що найближчі до озера місця «дикого» вимивного видобутку бурштину розташовані в межах 0,7-2,0 км від озера.

Цією загрозою є порушення сольового балансу водойм Рівненського природного заповідника, оскільки вода, що використовується як при масштабному, так і при дрібному видобутку бурштину, повертається в водойми з підвищеним солевмістом.

Основними об'єктами порівняльних досліджень були води озеро Біле Володимирецького району та води інших водойм Рівненського природного заповідника.

Сьогодні в Україні існує три шляхи добування бурштинусукциніту:

- свердловинне видобування шляхом шнекового буріння - на породу діють гідравлічним тиском і пульпа, що містить бурштин, виноситься на поверхню [2];

- кар'єрне добування бурштину - найнебезпечніший для навколишнього середовища метод;

- «вимивання» - незаконний метод, який передбачає закачування води $з$ найближчої водойми під високим тиском в ґрунт з метою вертикального розмиву. Таким чином утворюються свердловини глибиною до 10 метрів. Бурштин разом з водою переноситься на поверхню, де вилучається вручну.

\section{Порівняльний аналіз поверхневих вод і вод, що накопичуються в свердловинах «дикого» видобування}

Вкрай низький природний рівень мінералізації поверхневих вод при практично повній відсутності в них біогенних мінеральних 186 
елементів $є$ особливістю хімічного складу поверхневих вод на території Рівненського природного заповідника. Цей факт підтверджують дані, наведені в табл. 1.

Завдяки такому вмісту розчинених солей, у водоймах склався унікальний склад мікрофлори, а також видовий склад прибережної рослинності. Зміна існуючого сольового складу, особливо у бік збільшення загального солевмісту, може призвести до безповоротного порушення хімічної і біологічної рівноваги водойм, що є критично неприйнятним для заповідних територій.

При проведенні серії аналізів води у свердловинах на місцях нелегального видобутку бурштину нами було виявлено, що після контакту з породами всередині свердловин загальна твердість води суттєво зростає, в межах 0,7-2,0 ммольекв/дм³ (при природній твердості 0,3 ммоль-екв/дм³). Проте, «дикий» спосіб видобування бурштину не передбачає жодних заходів для обмеження зливу більш мінералізованої води зі свердловин у природні поверхневі водойми.

Це власне і є суть прихованої проблеми. Змішування поверхневих вод з глибинними породами, зумовлене розмиванням свердловин, може призводити до переходу катіонів і аніонів з підземних вод (в тому числі, біогенних) до поверхневих вод водойм і змінювати в них наявний сталий хімічний склад води. Солі кальцію (одна з головних складових солей твердості) є біогенними. В свою чергу, порушення балансу біогенних елементів здатне призвести до неминучих порушень біологічної рівноваги, а такі зміни є неприйнятним для природного заповідника. В зв'язку з виявленням цієї проблеми необхідно розробити і приймати заходи щодо захисту водного басейну, які би мали як законодавчий, так і технологічний характер.

\section{Фізико-хімічні дослідження і аналіз їх результатів}

Загальну твердість води в озері Білому та в його околицях можна вважати сталим у часі параметром, тому зміна значення твердості $\epsilon$ певним маркером того, негативного впливу техногенного та/або антропогенного характеру.

Нами були відібрані зразки води та винесеної породи зі свердловини на місці нелегального видобутку бурштину. Свердловина розташована приблизно в 700 м від кромки озера Біле біля старих очисних споруд реабілітаційно-оздоровчого комплексу «Біле озеро». Вода аналізувалася на вміст солей твердості, вимірювалось значення $\mathrm{pH}$, зразок породи був підданий рентгенофазовому аналізу (рисунок). 


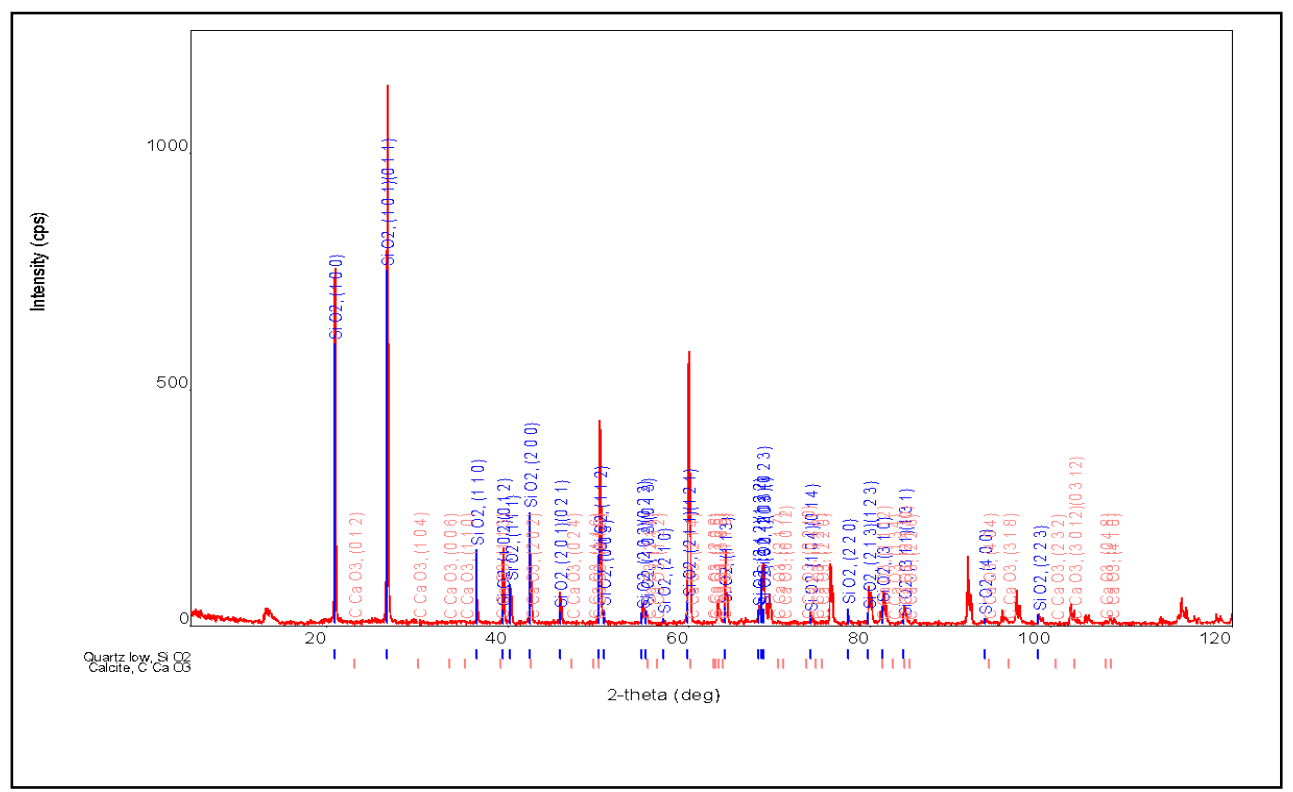

Рисунок. Дифрактограма складу зразка ґрунту

Дані дифратомерії дозволяють стверджувати, що одним із породоутворюючих мінералів неглибокого залягання $\in \mathrm{CaCO}_{3}$. Таким чином, вміст катіонів кальцію у вимивній воді пояснюється саме наявністю у породі кальцієвмісного мінералу і контактом води з цим мінералом.

Це не протирічить відомим з наукової літератури даним щодо мінералів, які $є$ імовірними супутниками мінералів сукцинітової групи [3].

Розчинність $\mathrm{CaCO}_{3}$ солі може бути математично змодельована при різних рН за наступною схемою:

$$
\begin{gathered}
\mathrm{CaCO}_{3} \leftrightarrow \mathrm{Ca}^{2+}+\mathrm{CO}_{3}{ }^{2-} \\
{\left[\mathrm{Ca}^{2+}\right]=\mathrm{C} ;\left[\mathrm{CO}_{3}{ }^{2-}\right]=\mathrm{CC} .}
\end{gathered}
$$

Тоді:

$$
\begin{gathered}
\not \mathrm{CaCO}_{3}=\left[\mathrm{Ca}^{2+}\right] \cdot\left[\mathrm{CO}_{3}^{2-}\right]=3,8 \cdot 10^{-9} ; \\
Д P_{\mathrm{CaCO}_{3}}=C^{2},
\end{gathered}
$$

де $Д \mathrm{CaCO}_{3}$ - добуток розчинності карбонату кальцію.

Перебіг дисоціації карбонатної кислоти, що утворюється, здійснюється в дві стадії [1]:

$$
\begin{gathered}
\mathrm{CO}_{3}{ }^{2-}+\mathrm{H}^{+} \leftrightarrow \mathrm{HCO}_{3}^{-} ; \\
\mathrm{K}_{1, \mathrm{~K}}=\left[\mathrm{CO}_{3}^{2-}\right] \cdot\left[\mathrm{H}^{+}\right] /\left[\mathrm{HCO}_{3}{ }^{-}\right] ; \\
\mathrm{HCO}^{3-}+\mathrm{H}^{+} \leftrightarrow \mathrm{H}_{2} \mathrm{CO}_{3} ; \\
\mathrm{K}_{2, \mathrm{~K}}=\left[\mathrm{HCO}_{3}^{-}\right] \cdot\left[\mathrm{H}^{+}\right] /\left[\mathrm{H}_{2} \mathrm{CO}_{3}\right] .
\end{gathered}
$$


Отже:

$$
\mathrm{C}=\left[\mathrm{HCO}_{3}{ }^{-}\right]+\left[\mathrm{CO}_{3}{ }^{2-}\right]+\left[\mathrm{H}_{2} \mathrm{CO}_{3}\right] .
$$

Знаходимо залежність рівноважної концентрації іонів $\mathrm{Ca}^{2+}$ від $\mathrm{pH}$ середовища в тих областях кислотності, де ця концентрація контролюється розчинністю карбонату кальцію:

$$
\left[\mathrm{Ca}^{2+}\right]=\left[\frac{\Pi P_{\mathrm{CaCO}_{3}} \cdot\left(\left[\mathrm{H}^{+}\right]^{2}+K_{1, \kappa} K_{2, \kappa}\left[\mathrm{H}^{+}\right]+K_{1, \kappa} K_{2, \kappa}\right)}{K_{1, \kappa} K_{2, \kappa}}\right]^{\frac{1}{2}} .
$$

Вочевидь, що для карбонату магнію і сульфату кальцію відповідні залежності типу (10) будуть мати аналогічний вигляд зі специфічними значеннями добутків розчинностей солей, констант іонізації кислот, коефіцієнтів активностей іонів.

Твердість води класифікується як тимчасова (або карбонатна)

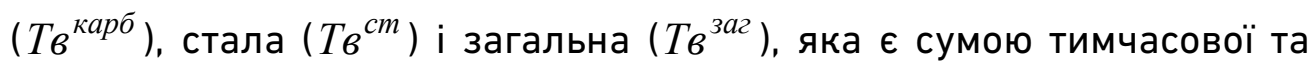
сталої.

$$
T b^{3 a z}=T 8^{\text {карб }}+T \boldsymbol{b}^{c m} .
$$

Карбонатна твердість визначається наявністю у воді розчинних солей вугільної (карбонатної) кислоти - гідрокарбонатів кальцію або магнію, переважно кальцію. Цей вид твердості $€$ найбільш стабільним і присутній у воді практично завжди.

Стала твердість - це вміст всіх інших розчинних солей кальцію та магнію (хлоридів, нітратів, сульфатів та гідросульфатів). На відміну від карбонатної, стала твердість у воді може з'являтися внаслідок тимчасових процесів, пов'язаних з раптовим потраплянням солей кальцію та магнію у воду. Це можуть бути наслідки антропогенної або ж техногенної діяльності.

Отже, карбонатна твердість свідчить про сталість мінерального складу води, а стала твердість - про можливі коливання мінерального складу води.

$$
T b^{c m}=T b^{3 a 2}-T b^{\text {карб }} .
$$

Звідки розчинність кальцію, доданого у вигляді сталої твердості (моль/дм³ ${ }^{3}$ молярна маса кальцію 40 г/моль), становить

$$
S_{C a}=\frac{T b^{c m} \cdot 2}{1000} .
$$

Це, власне, та частка розчиненого кальцію, яка привноситься до води ззовні через певні природні чинники або через втручання людини. 
Таким чином, відповідно до рівнянь (12) та (13), за даними первинних польових і лабораторних аналізів, твердість води для об'єктів, пов'язаних з техногенною діяльністю (меліоративні канали та канали, до яких скидаються води розробок бурштину) складає (табл. 2):

Таблиця 2

Твердість стічної води

\begin{tabular}{|c|c|c|c|c|}
\hline Об'єкт & $\begin{array}{c}\text { Загаль- } \\
\text { на твер- } \\
\text { дість } \\
\text { води, } \\
\text { ммоль- } \\
\text { екв/дм³ }\end{array}$ & $\begin{array}{c}\text { Карбонатна } \\
\text { твердість во- } \\
\text { ди, } \\
\text { ммоль·екв/д } \\
\mathrm{M}^{3}\end{array}$ & $\begin{array}{c}\text { Стала твер- } \\
\text { дість води, } \\
\text { ммоль-екв/д } \\
\mathrm{M}^{3}\end{array}$ & $\begin{array}{c}\text { Розчин- } \\
\text { ність іонів } \\
\text { кальцію, } \\
\text { ммоль/дм } \\
3\end{array}$ \\
\hline $\begin{array}{c}\text { Накопичу- } \\
\text { вальна ка- } \\
\text { нава, } \\
\text { с. Пугач }\end{array}$ & 10,8 & 0,8 & 10,8 & 0,02 \\
\hline $\begin{array}{c}\text { Меліорати- } \\
\text { вний канал } \\
\text { кв. 45 }\end{array}$ & 3,5 & 1,6 & 1,9 & 0,0038 \\
\hline $\begin{array}{c}\text { Меліорати- } \\
\text { вний канал } \\
\text { біля бобро- } \\
\text { вих хаток }\end{array}$ & 5,5 & 1,2 & 4,3 & 0,0086 \\
\hline Розрахована & & & \\
\hline
\end{tabular}

Розрахована розчинність кальцію знаходиться в межах розчинності вапняку $\left(6,16 \cdot 10^{5}\right.$ моль/дм $\left.{ }^{3}\right)$ та гіпсу $\left(0,005\right.$ моль/дм $\left.{ }^{3}\right)$. Неможливо врахувати розведення води внаслідок тривалості руху води, проте цілком імовірно, що при видобуванні бурштину до природної води потраплять саме ці мінерали, які і зумовлюють збільшення вмісту кальцію у воді.

В принципі, потенційна загроза для водних об'єктів Рівненського природного заповідника може полягати в тому, що при змішуванні природних, дуже слабкомінералізованих вод зі стоками видобутку бурштину матиме місце порушення біологічної рівноваги, при якому перевагу отримують ті рослинні та тваринні організми, які залежать від вмісту кальцію, наприклад, мушлеві молюски, хребетні. Однак без встановлення точного джерела потрапляння кальцію важко створити повну модель, яка описувала би несприятливі наслідки збільшення концентрації кальцію у воді.

Для подальшого з'ясування питання, чи є дана концентрація 
кальцію надмірною, доцільно використати відомий у ксенобіології так званий коефіцієнт надлишку [4].

Коефіцієнт надлишку хімічного елементу (в даному випадку, кальцію) $K_{\text {са }}$ - це безрозмірна величина, відношення концентрації елементу у рослині до їі відношення у навколишньому середовищі. Коефіцієнт надлишку є термодинамічною величиною, тобто враховує вміст речовини у стані хімічної (біохімічної), біологічної рівноваги із навколишнім середовищем і ніяк не враховує кінетику накопичення цієї речовини як в навколишньому середовищі до рівноважного (максимально можливому за поточних умов) стану, так і кінетику засвоювання елементу рослинами та його акумуляцію у організмі до максимального значення. Проте, коефіцієнт накопичення фактично $є$ граничним параметром, який кількісно характеризує, чи може за даних навколишніх умов елемент стати біологічно небезпечним для тієї чи іншої рослини.

$$
K_{C a}=\frac{[\mathrm{Ca}]^{\text {рослина }}}{[\mathrm{Ca}]^{\text {навк.серед }}} \cdot 100 .
$$

Знаменник в формулі (14), [Ca $]^{\text {навк.серед }}$ - це, фактично, рівноважна концентрація катіонів кальцію, розрахована в залежності від кислотності середовища відповідно до рівняння 10. Але, для коректного обрахування системи рівнянь (10) та (11), тобто адекватно вірогідного математичного моделювання накопичення кальцію до небезпечних кількостей потрібні точні практичні дані щодо реального вмісту кальцію у тих чи інших рослинах, які ростуть на території Рівненського природного заповідника, одержані спільними зусиллями фахівців з ботаніки та хімії. За браком точних даних нами наведено лише узагальнені коефіцієнти накопичення [4] (табл. 3).

Таблиця 3

Узагальнені коефіцієнти накопичення кальцію деякими рослинами

\begin{tabular}{|c|c|c|c|c|}
\hline \multicolumn{4}{|c|}{ Рослина } & \multirow{2}{*}{$\begin{array}{l}\text { Середній } \\
\text { показник }\end{array}$} \\
\hline Кладофора & $\begin{array}{c}\text { Нижчі } \\
\text { рослини }\end{array}$ & Елодея & $\begin{array}{c}\text { Вищі } \\
\text { рослин }\end{array}$ & \\
\hline 330 & 185 & 500 & 330 & 290 \\
\hline
\end{tabular}

Аналіз рівняння (14) та даних таблиці 3 щодо катіонів кальцію дає підставу стверджувати, що цей елемент буде накопичуватися в рослинних організмах досить легко, адже значення відповідного коефіцієнту накопичення є найнижчим серед наведених. Крім того, розчинність можливих мінералів буде тим більшою, чим вищою є кислотність природної води або чи слабкішою є кислота, з якої було 
утворено природний мінерал. Перешкодити ж накопиченню в водах елементів і речовин в непритаманних їм кількостям можна шляхом впровадження відпрацьованих у промисловості технологій та прийомів [5].

\section{Висновки}

Низький солевміст та твердість вод озера Біле та ряду інших водойм розташованих на території Рівненського природного заповідника підтверджені довготривалими, дозволяють використовувати їх, як еталон для проведення випробувань водоочисного обладнання як в масштабних установках, так і штучних виробах індивідуального вжитку.

Отримані дані підтверджують високу цінність вод озера Біле не лише як унікального екологічного елемента Рівненського природного заповідника, так і практичного використання невеликих об'ємів цих вод.

Зважаючи на це, має бути приділена максимальна увага контролю та запобіганню нелегального бурштинового видобутку і, як наслідок, зливанню стічних вод в водойми на територіях, наближених до заповідних. Сьогодні незаконний видобуток дуже активно ведеться на територіях що межують з заповідником, а поодинокі свердловини є на його території. Це питання має вирішуватися спільними зусиллями співробітників наукових установ, заповідника, міністерством екології та природних ресурсів, міністерством внутрішніх справ України.

1. Лапінський А. В., Толстопалова Н. М., Кримець Г. В., Савицька М. А., Костоглод О. Б. Хімічні методи виявлення техногенного та антропогенного навантаження на природні водні об'єкти. Природа Полісся: дослідження та охорона : матеріали міжнародної науково-практичної конференції, присвяченої 15-річчю Рівненського природного заповідника та 10-річчю Рамсарського угіддя «Торфово-болотяний масив Переброди». Рівне : Овід, 2014. С. 198-200. 2. Бетехтин А. Г. Курс минералогии : учебное пособие. М. : КДУ, 2007. 721 с. 3. Богдасаров М. А. Янтарь из антропогеновых отложений Беларуси. Брест : Изд-во С. Лаврова, 2001. 124 с. 4. Юрин В. М. Основы ксенобиологии : учеб. пособие. М. : Новое знание, 2002. 267 с. 5. Vaughn J. Waste Management: A Reference Handbook (Contemporary World Issues Series). Jacqueline Vaughn. Santa Barbara, Kalifornia, USA : ABC-CLIO, 2009. 271 p.

\section{REFERENCES:}

1. Lapinskyi A. V., Tolstopalova N. M., Krymets H. V., Savytska M. A., Kostohlod 0. B. Khimichni metody vyiavlennia tekhnohennoho ta antropohennoho navantazhennia na pryrodni vodni obiekty. Pryroda Polissia: 
doslidzhennia ta okhorona : materialy mizhnarodnoi naukovo-praktychnoi konferentsii, prysviachenoi 15-richchiu Rivnenskoho pryrodnoho zapovidnyka ta 10-richchiu Ramsarskoho uhiddia «Torfovo-bolotianyi masyv Perebrody». Rivne : Ovid, 2014. S. 198-200. 2. Betekhtin A. H. Kurs mineralohii : uchebnoe posobie. M. : KDU, 2007. 721 s. 3. Bohdasarov M. A. Yantar iz antropohenovykh otlozhenii Belarusy. Brest : Izd-vo S. Lavrova, 2001. 124 s. 4. Yurin V. M. Osnovy ksenobiolohii : ucheb. posobie. M. : Novoe znanie, 2002. 267 s. 5. Vaughn J. Waste Management: A Reference Handbook (Contemporary World Issues Series). Jacqueline Vaughn. Santa Barbara, Kalifornia, USA : ABC-CLIO, 2009. $271 \mathrm{p}$.

Lapinskyi A. V., Candidate of Engineering (Ph.D.), Kuzminchuk A. V., Post-graduate Student, Astrelin I. M., Doctor of Engineering, Professor, Krymets H. V., Candidate of Engineering (Ph.D.) (National Technical University of Ukraine "Igor Sikorsky Kyiv Polytechnic Institute", Kyiv), Harashchenko 0. V., Candidate of Engineering (Ph.D.), Associate Professor (National University of Water and Environmental Engineering, Rivne)

\section{EXEMPLARY NATURAL WATERS AND THE PROBLEM OF THEIR CONSERVATION IN WATER BODIES}

The waters of the surface reservoirs of the Rivne Nature Reserve, and in particular the lake Bile, have an abnormally low salt content and hardness. This fact confirms the results of our multi-year and systematic studies of water samples. We have investigated these and others indicators of water condition for 8 years from 2011 to today's time. In this article are used the materials of water analysis until 2018 inclusive. The text deals with the analysis of relative systematized data. We used trilonometric titration for water hardness level definition, IMF methods for $\mathrm{pH}$ and total salt content determination and $x$-ray for soil analysis. This made it possible to draw conclusions about the possibility of using Lake Bile water as benchmarks for testing equipment and computer simulation of water treatment processes. Two main steps to realize it is to thoroughly examine such sources of natural water and to develop a reliable system for monitoring and protecting these natural sources from man-made and anthropogenic influences in order to maintain their composition in a stable state in the medium and long-term, that is, from 10 years or more. Also, we considered are factors that may have a negative impact on the salt content of the water. In particular, the consequences of amber mining are considered. We identified the 
hidden problem in this process. The waters of a deep ground ambercarrying layers have significantly higher rates of hardness and salt content. According to difractometric analysis the soil samples taken from amber mining wells contain $\mathrm{CaCO} 3$ (calcium carbonate). It can easily dissolve in water and rise a hardness salt content. That's why we can make a conclusion, that when surface water, which contacts with these minerals is arrived back to the water reservoirs it can break the salt balance. As a result in some time it may change biodiversity and lead to the extinction of unique plant species. In this text we show only the chemical part of this problem. It also requires consideration by the biologists and ecologists. Our investigations are still in process, and we are working on simple and cheap technological decision of this problem. Keywords: surface water, low water hardness, biogenic elements, physical and chemical research of water composition, amber.

Лапинский А. В., к.т.н, Кузьминчук А. В., аспирант, Астрелин И. М., д.т.н., профессор, Кримец Г. В., к.т.н. (Национальный технический университет Украины «Киевский политехнический институт имени Игоря Сикорского», Киев), Гаращенко О. В., к.т.н., доцент (Национальный университет водного хозяйства и природопользования, г. Ровно)

\section{ОБРАЗЦОВАЯ ПРИРОДНАЯ ВОДА И ПРОБЛЕМЫ ЕЕ СОХРАНЕНИЯ В} ВОДОЕМАХ

Воды поверхностных водоемов Ровенского природного заповедника, в частности, озера Белое, имеют аномально низкое солесодержание и жесткость. Этот факт подтверждают результаты проведенных нами многолетних и системных исследований проб воды. В статье приведены анализ соответствующих систематизированных данных. Это позволило сделать выводы о возможности применения вод озера Белое, как эталонных для испытания оборудования и компьютерного моделирования водоочистных процессов. Рассмотрены факторы, которые могут оказать негативное влияние на солевой баланс вод (в частности, последствия добычи янтаря). Ключевые слова: поверхностные воды, низкая жесткость, биогенные элементы, физико-химические исследования состава воды, янтарь. 